\title{
KARAKTERISTIK PULP KIMIA MEKANIS DARI KENAF (Hibiscus cannabinus L.) UNTUK KERTAS LAINER
}

\author{
Teddy Kardiansyah ${ }^{1}$, Susi Sugesty \\ Balai Besar Pulp dan Kertas, Jalan Raya Dayeuhkolot No. 132, Bandung \\ ${ }^{1}$ teddysyah83@gmail.com
}

Diterima : 6 Maret 2014, Revisi akhir : 12 Mei 2014, Disetujui terbit : 30 Mei 2014

\section{CHARACTERISTIC OF CHEMIMECHANICAL PULP FROM KENAF (Hibiscus cannabinus L.) FOR LINER PAPER}

\begin{abstract}
Liner paper is commonly used for packaging because of its high bursting and ring crush strength. To meet these properties, liner paper strength relies on about 10-40\% content of NUKP (Needle Unbleached Kraft Pulp). Currently, Indonesia does not produce NUKP, so it must be imported and the price is expensive. Liners paper in Indonesia is usually made from waste paper (old corrugated containers) that has unacceptable strength properties. To improve the strength properties, virgin pulp should be used. This study aimed to make virgin pulp from kenaf by chemimechanical process. Its physical strength was tested as a NUKP substitute. The results show that Kenaf mechanical pulp from Kenaf bast treated by using $6 \%$ sodium hydroxide solution fulfills the NUKP specifications according to SNI- 6106-1999, i.e. a fiber length of $4.24 \mathrm{~mm}$, a freeness of $760 \mathrm{~mL} \mathrm{CSF}$, a tensile index of $66.54 \mathrm{Nm} / \mathrm{g}$, a burst index of $5.72 \mathrm{kPam} 2 / \mathrm{g}$, and a tear index of $18.09 \mathrm{mNm} 2 / \mathrm{g}$.
\end{abstract}

Keywords: nonwood, chemimechanical pulp, kenaf, bast, core

\section{ABSTRAK}

Kertas lainer merupakan kertas industri yang digunakan untuk kemasan, dengan sifat ketahanan retak dan ketahanan tekan lingkar (ring crush) yang tinggi. Untuk mendapatkan kedua sifat tersebut maka biasanya kekuatan kertas lainer bertumpu pada penggunaan NUKP (pulp kraft serat panjang belum putih) dengan proporsi sekitar $10-40 \%$. Saat ini Indonesia tidak memproduksi NUKP sehingga kebutuhan NUKP harus diimpor dan harganya mahal. Kertas lainer di Indonesia pada saat ini hampir semuanya dibuat dari karton bekas, disamping itu pengolahan karton bekas memiliki masalah pada kekuatan lembaran. Jika pembuatan karton menggunakan serat asli (virgin pulp), maka masalah kekuatan lembaran dapat diatasi. Penelitian ini bertujuan untuk membuat pulp dari Kenaf dengan proses kimia mekanis. Bahan baku nonkayu yaitu kenaf dibuat pulp mekanis dengan menggunakan proses Chemimechanical Pulp (CMP). Selanjutnya pulp mekanis yang diperoleh diuji kekuatan fisiknya untuk melihat potensinya sebagai pulp NUKP. Pulp mekanis kenaf yang berasal dari kulit kenaf dengan penggunaan natrium hidroksida $(\mathrm{NaOH}) 6 \%$ telah memenuhi spesifikasi pulp NUKP sesuai dengan SNI 6106-1999, yaitu panjang serat 4,24 mm, freeness $760 \mathrm{~mL} \mathrm{CSF}$, indeks tarik 66,54 Nm/g, indeks retak $5,72 \mathrm{kPam}^{2} / \mathrm{g}$ dan indeks sobek $18,09 \mathrm{mNm}^{2} / \mathrm{g}$.

Kata kunci: non kayu, pulp kimia mekanis, kenaf, kulit, batang tanpa kulit

\section{PENDAHULUAN}

Kenaf (Hibiscus cannabinus L.), tanaman tropis tahunan cepat tumbuh dari keluarga Malvaceae, digunakan terutama untuk benang, kanvas, dan karung. Selama satu dekade terakhir telah banyak diteliti karena merupakan bahan nonkayu yang berpotensi digunakan sebagai bahan baku pulp dan kertas seperti kertas koran dan kertas lainer karena meningkatnya permintaan global untuk kebutuhan kertas dan produk kertas (Ibrahim dkk., 2011). 
Negara penghasil kenaf adalah India, Cina, dan Thailand, yang telah memproduksi kenaf lebih dari 95\% kebutuhan dunia. Pada 20052006 , total produksi kenaf adalah 0,33 juta ton yang didominasi oleh India, China dan Thailand yang masing-masing menghasilkan 42\%, 25\% dan $11 \%$, sedangkan sisanya dihasilkan oleh negara-negara lain (Mosello, 2010).

Kenaf dapat mencapai tinggi 4-5 m dengan diameter batang $25-35 \mathrm{~mm}$ dengan siklus pertumbuhan $5-7$ bulan (Nezamoleslami dkk., 1997). Batang kenaf mengandung dua komponen serat yaitu serat kulit dan serat inti kayu yang karakteristik sifat kimia dan morfologinya sangat berbeda. Umumnya, bagian kulit menyumbang sekitar 35\% dari massa batang, dan sisanya kayu bagian inti. Kulit kenaf berserat panjang dan ramping dengan kadar selulosa tinggi, sedangkan serat inti jauh lebih pendek dan lebih lebar dengan kandungan lignin yang lebih tinggi (Khalil dkk., 2010; Mossello dkk., 2009). Serat kulit dan inti berbeda sifat dan struktur, sehingga dua jenis serat ini menunjukkan perilaku yang berbeda selama proses pembuatan kertas. Serat inti mengandung proporsi serat yang rendah dan komponen yang berasal dari pith (sel gabus) (Villar dkk., 2009) sehingga memiliki derajat giling yang rendah (Calabro, 1992). Hal ini merupakan alasan untuk membatasi penggunaan serat inti, yang mungkin lebih baik digunakan tanpa melalui proses penggilingan (Kaldor, 1989). Sebaliknya, serat kulit mudah digiling dan dapat mengembangkan sifat kekuatan serat (Villar dkk., 2009; Calabro, 1992).

Kualitas serat kulit dan inti memiliki perbedaan sehingga beberapa peneliti telah mengusulkan pemisahan serat inti dan kulit (Villar dkk., 2009; Nezamoleslami dkk., 1997; Ren dkk., 1996; Calabro,1992; Kaldor, 1989) atau menyesuaikan rasio campuran berdasarkan sifat produk yang diperlukan (Villar dkk., 2009). Di sisi lain, penggunaan batang kenaf secara keseluruhan (kulit pohon dan inti bersamasama) dapat menguntungkan dari aspek teknis dan ekonomis (Ververis dkk., 2004; Khristova dkk., 2002). Penelitian kenaf sebagai bahan baku untuk pulp telah dilakukan oleh USDA di Amerika Serikat sejak 1960. Penelitian oleh USDA sempat terhenti pada tahun 1970 ketika perhatian beralih ke krisis energi, tetapi penelitian lanjutan dilakukan oleh sektor swasta (Liu, 2002). Saat ini, penelitian pembuatan pulp kenaf juga telah banyak dilakukan.Mossello dkk. (2010) melakukan penelitian pembuatan pulp kenaf dengan proses soda-antrakuinon, alkaline pulping, alkaline sulfite-anthraquinone (AS-AQ), ASAM (alkaline sulfite-anthraquinonemethanol) (Khristova, 2002), proses kraft (Villar dkk., 2009).

Kertas lainer merupakan kertas industri yang digunakan untuk kemasan, dengan sifat ketahanan retak dan ketahanan tekan lingkar (ring crush) yang tinggi. Kedua sifat tersebut biasanya diperoleh dengan menggunakan NUKP (pulp kraft serat panjang belum putih) dengan proporsi sekitar $10-40 \%$. Saat ini, Indonesia tidak memproduksi NUKP sehingga kebutuhan NUKP harus diimpor dan harganya mahal. Kertas lainer di Indonesia pada saat ini hampir semuanya dibuat dari karton bekas, disamping itu pengolahan karton bekas memiliki masalah pada kekuatan lembaran. Jika pembuatan karton menggunakan serat asli (virgin pulp), maka masalah kekuatan lembaran dapat diatasi. Penelitian ini bertujuan untuk membuat pulp dari Kenaf dengan proses kimia mekanis untuk menghasilkan pulp dengan karakteristik sesuai dengan NUKP. Sehingga pulp kenaf diharapkan dapat menjadi salah satu alternatif bahan baku untuk pembuatan kertas yang menggunakan bahan baku pulp NUKP.

\section{BAHAN DAN METODE}

Kenaf yang digunakan berasal dari daerah Malang. Bahan baku kenaf yang digunakan dalam penelitian ini terdiri dari tiga bagian yaitu kulit kenaf (bast), campuran dan batang kenaf tanpa kulit (core) yang disajikan dalam Gambar 1.

Tahapan penelitian meliputi persiapan bahan baku, analisis morfologi serat bahan baku, analisis komponen kimia bahan baku, pembuatan pulp, pembuatan lembaran pulp serta penentuan sifat fisik pulp.

Penentuan morfologi serat Kenaf meliputi panjang serat (maksimum, minimum dan ratarata), tebal dinding serat, dan nilai turunannya yaitu bilangan Runkel, kelangsingan dan kelemasan. Metode pengujian yang digunakan adalah prosedur Standar Nasional Indonesia (SNI) 01-1840-1990, Cara uji panjang serat kayu dan bukan kayu. Analisis komponen kimia kenaf dilakukan menurut SNI, meliputi kadar holoselulosa (SNI 01-1303-1989, Cara uji kadar holoselulosa kayu), alfa selulosa, lignin (SNI 0492:2008, Pulp dan kayu-Cara uji kadar lignin- 
Metode Klason), pentosan (SNI 01-1561-1989 Cara uji pentosan kayu), abu (SNI 0442:2009, Kertas, karton dan pulp- Cara uji kadar abu pada 525 derajat Celcius), sari (ekstrak alkoholbenzena) (SNI 01-1032-1989, Cara uji kelarutan dalam alkohol benzene), kelarutan dalam air dingin dan air panas (SNI 01-1305-1989) dan dalam 1\% NaOH (SNI 01-1033-1989, Cara uji kelarutan dalam larutan $\mathrm{NaOH} 1 \%$ ).

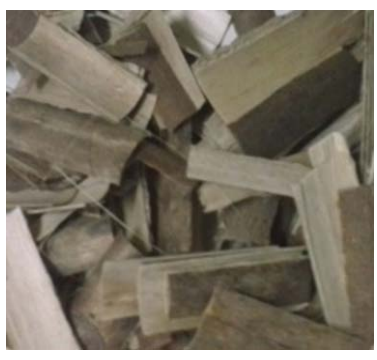

(a)

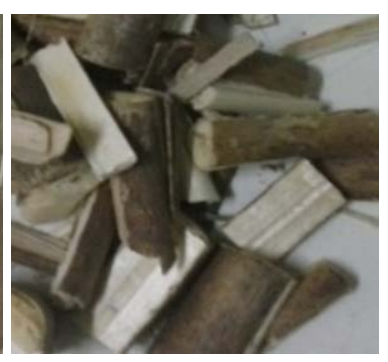

(b)

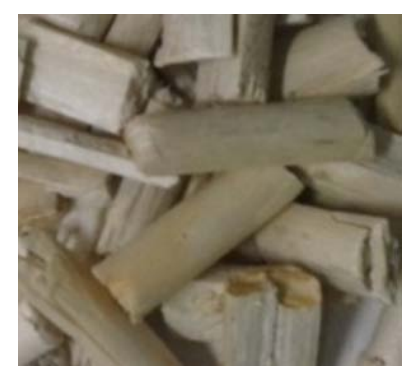

(c)

Gambar 1. Bahan Baku Kenaf (a) Kulit Kenaf (Bast), (b) Campuran dan (c) Batang Kenaf tanpa Kulit (Core)

Penilaian klasifikasi turunan dimensi serat berdasarkan kriteria karakteristik kayu untuk pulp yang dipaparkan dalam Aprianis dan Rahmayanti (2009). Penilaian berdasarkan nilai karakteristik turunan dimensi serat yang diberikan skor, selanjutnya skor dikompilasi sehingga diperoleh nilai akhir yang akan merujuk kepada nilai kelas tertentu.

Bahan baku kenaf dibagi menjadi tiga bagian yaitu kulit kenaf (bast), batang kenaf (stalk), untuk selanjutnya batang kenaf akan disebutkan campuran saja dan batang kenaf tanpa kulit (core). Pemasakan kenaf dilakukan dengan cara pemanasan menggunakan bahan kimia $\mathrm{NaOH}$ dalam autoklaf dengan variasi dosis $6 \%$, $8 \%, 10 \%$ dan $12 \%$ dan dibuat pulp. Pulping dilakukan dalam digester putar (rotary digester) dalam udara panas yang dapat dikontrol. Tujuan utama pulping adalah untuk melunakkan kenaf dengan bahan kimia sehingga akan mudah untuk diuraikan (refining). Kondisi pulping pada temperatur $150^{\circ} \mathrm{C}$, waktu pemasakan pada suhu maksimum selama 1,5 jam.

Kenaf yang telah dimasak selanjutnya diuraikan dalam refiner halus untuk mendapatkan pulp. Setelah itu dilakukan penyaringan menggunakan saringan bergetar (flat screen) untuk memisahkan serat-serat halus dan seratserat kasar (atau bundelan serat). Setelah itu seratserat halus (produk pulp mekanis) ditentukan yield/rendemennya.

Untuk pengujian sifat fisik, sebelum dibuat lembaran, pulp digiling dalam Valley Beater. Variasi derajat giling ditentukan berdasarkan variasi waktu giling yang diukur dengan menggunakan CSF (Canadian Standard Freeness Tester) berdasarkan SNI ISO 5267-2:2001, IDT, Pulp-Cara uji kemampuan drainase- bagian 2 : metode Canadian Standard Freeness, selanjutnya dilakukan pengujian sifat fisik lembaran pulp, yang terdiri dari indeks sobek, indeks retak dan indeks tarik.

Pengujian indeks sobek dilakukan menurut SNI 0436:2009, Kertas - Cara uji ketahanan sobek - Metode Elmendorf; indeks retak menurut SNI ISO 2758:2011, Kertas - Cara uji ketahanan retak; dan indeks tarik menurut SNI ISO 19242:2010, Cara uji sifat tarik-Bagian 2: Metode kecepatan elongasi tetap.

\section{HASIL DAN PEMBAHASAN}

\section{Morfologi Serat Kenaf}

Morfologi serat merupakan salah satu sifat penting bahan baku yang dapat digunakan sebagai dasar memilih bahan baku untuk produksi pulp dan kertas. Morfologi serat (panjang serat, diameter serat, tebal dinding sel, lebar lumen) dari bagian tanaman kenaf disajikan pada Tabel 1.

Menurut klasifikasi IAWA (Anonim, 1932) dalam Aprianis dan Rahmayanti (2009), kulit kenaf termasuk kelas serat panjang yaitu 4,24 $\mathrm{mm}$, sedangkan batang kenaf termasuk kelas medium dengan panjang serat 1,41 mm. Menurut Tamolang dan Wangaard (1961) dalam Aprianis dan Rahmayanti (2009), bahwa semakin panjang serat kayu maka pulp yang dihasilkan memiliki kekuatan yang tinggi. Hal ini disebabkan serat panjang memberikan bidang persentuhan yang lebih luas dan anyaman lebih baik antara satu serat dengan lainnya, yang memungkinkan lebih 
Tabel 1. Morfologi Serat Bagian Tanaman Kenaf

\begin{tabular}{clcc}
\hline No & \multicolumn{1}{c}{ Parameter } & Kulit & Batang tanpa kulit \\
\hline 1 & Panjang serat (L), mm & 4,24 & 1,41 \\
2 & Diameter luar (D), $\mu \mathrm{m}$ & 28,09 & 33,89 \\
3 & Diameter dalam (lumen) (1), $\mu \mathrm{m}$ & 10,33 & 20,15 \\
4 & Tebal dinding (w), $\mu \mathrm{m}$ & 8,88 & 6,87 \\
\hline
\end{tabular}

Tabel 2. Besaran Nilai Turunan Dimensi Serat Bagian Tanaman Kenaf

\begin{tabular}{clcc}
\hline No & Parameter & Kulit & Batang tanpa kulit \\
\hline 1 & Bilangan Runkel, 2w/1 & 1,72 & 0,68 \\
2 & Kekakuan, w/D & 0,32 & 0,20 \\
3 & Fleksibilitas, 1/D & 0,37 & 0,59 \\
4 & Daya Tenun, L/D & 150,94 & 41,61 \\
5 & Perbandingan Muhlstep (\%) & 86,48 & 64,65 \\
\hline
\end{tabular}

banyak terjadi ikatan hidrogen antar serat-serat tersebut. Lebih lanjut, pulp serat panjang lebih sulit lolos saringan, sehingga lebih mudah dicuci. Panjang serat mempengaruhi sifat-sifat tertentu pulp dan kertas, termasuk ketahanan sobek, kekuatan tarik dan daya lipat.

Diameter serat kulit kenaf $(28,09 \mu \mathrm{m})$ lebih kecil dari batang tanpa kulit kenaf $(33,89 \mu \mathrm{m})$. Sementara itu diameter lumen kulit kenaf sebesar $10,33 \mu \mathrm{m}$ dan batang kenaf 20,15 $\mu \mathrm{m}$. Tebal dinding serat kulit kenaf sebesar $8,88 \mu \mathrm{m}$ lebih tebal daripada batang kenaf yaitu $6,87 \mu \mathrm{m}$. Serat yang berdinding tipis mengakibatkan serat tersebut mudah pipih sehingga menghasilkan lembaran pulp dan kertas yang lebih padat dan ketahanan retak lebih baik dibandingkan dengan serat berdinding tebal. Sebaliknya, serat berdinding tebal menghasilkan lembaran yang mempunyai ketahanan sobek yang tinggi, tetapi ketahanan retaknya rendah. Untuk memperoleh ketahanan retak dan sobek yang tinggi, serat yang berdinding tebal perlu dicampur dengan serat yang panjang dan berdinding tipis (Aprianis dan Rahmayanti, 2009).

\section{Turunan Dimensi Serat}

Selain panjang serat, persyaratan serat untuk bahan baku pulp dan kertas juga ditentukan oleh nilai turunan dimensi serat. Nilai turunan dimensi serat (bilangan Runkel, perbandingan Muhlstep, fleksibilitas, koefisien kekakuan) dan nilai kelas serat untuk bagian tanaman kenaf dapat dilihat pada Tabel 2 dan Tabel 3.

Dari Tabel 2 terlihat bahwa bilangan Runkel untuk kulit kenaf adalah 1,72 dan batang kenaf 0,68 . Bilangan Runkel adalah perbandingan 2 kali tebal dinding sel dengan diameter lumen. Berarti bilangan Runkel berbanding lurus dengan tebal dinding sel dan berbanding terbalik dengan diameter lumen. Menurut Anonim (1976) bilangan Runkel kurang dari atau sama dengan 0,25 termasuk kelas I, batang kenaf termasuk ke dalam kelas III dan kulit kenaf termasuk ke dalam kelas IV. Bahan baku untuk pembuatan pulp serat yang baik yaitu memiliki bilangan Runkel kecil atau sama dengan 0,25 karena memiliki dinding sel yang tipis dan diameter lumen lebar sehingga serat dalam lembaran pulp dapat pipih seluruhnya dan ikatan antar serat baik (Aprianis dan Rahmayanti, 2009).

Nilai daya tenun yang dihasilkan dari kenaf berkisar antara 41-151 (Tabel 2). Nilai daya tenun merupakan perbandingan panjang serat dengan diameter serat. Semakin besar perbandingan tersebut maka semakin tinggi kekuatan sobek dan semakin baik daya tenun seratnya (Syafii dan Siregar, 2006). Menurut Anonim (1976), nilai daya tenun kenaf termasuk ke dalam kelas III dan kelas IV karena berkisar dari 41 sampai dengan 151. Perbandingan Muhlstep serat dari bagian tanaman kenaf tersebut berkisar antara 65-86 (Tabel 2). Menurut Anonim (1976), dari bagian tanaman kenaf tersebut dapat dibagi 
menjadi dua kelas perbandingan Muhlsteph. Kelas III dengan perbandingan Muhlsteph 60-80 untuk batang kenaf. Sedangkan yang termasuk kelas IV perbandingan Muhlsteph berkisar $>80$ untuk kulit kenaf. Besarnya perbandingan Muhlstep berpengaruh terhadap kerapatan lembaran pulp yang pada akhirnya berpengaruh pula pada kekuatan pulp yang dihasilkan. Semakin kecil perbandingan Muhlsteph maka kerapatan lembaran pulp yang dihasilkan akan semakin tinggi dengan sifat kekuatan tinggi pula. Sebaliknya, perbandingan Muhlsteph yang tinggi menghasilkan lembaran pulp dengan kerapatan yang rendah dan kekuatan rendah pula.

Koefisien kekakuan kulit dan batang kenaf adalah 0,32 dan 0,20 (Tabel 2). Perbandingan ini menunjukkan korelasi berlawanan terhadap kekuatan panjang putus (kekuatan tarik), artinya semakin tinggi koefisien kekakuan maka semakin rendah kekuatan tarik dari kertas tersebut. Sebaliknya semakin rendah koefisien kekakuan maka semakin tinggi kekuatan tarik kertasnya, maka untuk pembuatan pulp sebaiknya mempunyai nilai koefisien kekakuan yang rendah (Syafii dan Siregar, 2006). Kekakuan kulit kenaf masuk ke dalam kelas IV dan batang kenaf kelas III. Perbandingan fleksibilitas dari kulit dan batang kenaf adalah 0,37 dan 0,59. Perbandingan fleksibilitas adalah perbandingan diameter lumen dengan diameter serat, dimana perbandingan tersebut mempunyai hubungan parabolis dengan kekuatan tarik, artinya serat dengan perbandingan fleksibilitas tinggi berarti serat tersebut mempunyai tebal dinding yang tipis dan mudah berubah bentuk. Kemampuan berubah bentuk ini menyebabkan persinggungan antara permukaan serat lebih leluasa sehingga terjadi ikatan serat yang lebih baik dan akan menghasilkan lembaran pulp dengan kekuatan baik (Syafii dan Siregar, 2006).

Tabel 3 berikut menyajikan hasil penentuan skor dimensi serat dan nilai turunan dimensi serat pada bagian tanaman kenaf untuk penentuan klasifikasi serat kenaf. Berdasarkan Tabel 3, menurut klasifikasi dari Anonim (1976) dalam Aprianis dan Rahmayanti (2009), bagian tanaman kenaf tersebut termasuk kelas III. Dari data tersebut maka kenaf dianggap mempunyai potensi yang baik untuk menghasilkan pulp.

\section{Komponen Kimia Kenaf}

Analisis komponen kimia kayu bagian tanaman kenaf meliputi kadar holoselulosa, selulosa alfa, lignin, sari atau ekstraktif (ekstrak alkohol-benzena), pentosan, abu yaitu mineral, kelarutan bahan baku dalam $\mathrm{NaOH} 1 \%$, air panas dan air dingin. Tabel 4 menyajikan hasil penentuan kadar selulosa alfa untuk kulit, campuran dan batang tanpa kulit masing-masing adalah $45,90 \% ; 39,82 \%$ dan $38,53 \%$. Kadar selulosa alfa yang rendah mengindikasikan bahwa rendemen pulp yang diperoleh akan rendah pula. Menurut SNI 01-1303-1989, selulosa adalah polisakarida linier, terdiri dari satuan anhidroglukosa dengan ikatan 1-4 $\beta$ glukosidik yang pada hidrolisais dalam suasana asam menghasilkan D-glukosa. Kadar holoselulosa kulit, campuran dan batang tanpa kulit masing-masing adalah 81,59\%; $77,90 \%$ dan $75,60 \%$. Holoselulosa adalah bagian serat yang bebas sari (ekstraktif) dan lignin, terdiri dari selulosa dan hemiselulosa, berwarna putih

Tabel 3. Hasil Penetapan Skor Dimensi Serat dan Nilai Turunannya pada Kenaf untuk Penentuan Klasifikasi Seratnya

\begin{tabular}{clcc}
\hline No & \multicolumn{1}{c}{ Parameter } & Kulit & Batang tanpa kulit \\
\hline 1 & Panjang serat & 100 & 50 \\
2 & Bilangan Runkel, 2w/1 & 25 & 50 \\
3 & Kekakuan, w/D & 25 & 50 \\
4 & Fleksibilitas, 1/D & 25 & 50 \\
5 & Daya Tenun, L/D & 100 & 50 \\
6 & Perbandingan Muhlstep (\%) & 25 & 50 \\
7 & Skor Total & 300 & 300 \\
\hline
\end{tabular}


Tabel 4. Hasil Analisis Komponen Kimia Kenaf

\begin{tabular}{|c|c|c|c|c|c|c|}
\hline No & Parameter $(\%)$ & Kulit & Campuran & $\begin{array}{c}\text { Batang } \\
\text { tanpa } \\
\text { Kulit }\end{array}$ & $\begin{array}{c}\text { Batang } \\
\text { tanpa Kulit } \\
\text { (Han, 1998) }\end{array}$ & $\begin{array}{c}\text { Kulit } \\
\text { (Han, 1998) }\end{array}$ \\
\hline 1 & Kadar Abu & 4,64 & 4,51 & 2,62 & $2-4$ & $2-5$ \\
\hline 2 & Lignin & 10,16 & 17,04 & 22,75 & $15-21$ & $15-19$ \\
\hline 3 & $\begin{array}{l}\text { Ekstraktif (Ethanol- } \\
\text { Benzene) }\end{array}$ & 2,29 & 1,96 & 1,66 & - & - \\
\hline 4 & Holoselulosa & 81,59 & 77,90 & 75,60 & - & - \\
\hline 5 & Selulosa Alfa & 45,90 & 39,82 & 38,53 & $37-49$ & $44-57$ \\
\hline 6 & Pentosan & 16,48 & 22,47 & 23,80 & $18-24$ & $22-23$ \\
\hline 7 & Kelarutan Air Panas & 8,92 & 7,46 & 5,77 & - & - \\
\hline 8 & Kelarutan Air Dingin & 6,84 & 6,64 & 5,99 & - & - \\
\hline 9 & Kelarutan $1 \% \mathrm{NaOH}$ & 25,18 & 28,11 & 28,52 & - & - \\
\hline
\end{tabular}

sampai kekuning-kuningan. Kadar holoselulosa merupakan kadar total karbohidrat atau kadar polisakarida dalam bahan baku.

Pentosan merupakan bagian hemiselulosa dengan jumlah atom karbon 5 (C5). Hemiselulosa adalah polisakarida yang bukan selulosa, yang pada hidrolisa menghasilkan D-manosa, D-galaktosa, D-glukosa, D-xylosa, L-arabinosa dan asam-asam uronat. Kadar pentosan kulit, campuran dan batang tanpa kulit masing-masing adalah $16,48 \%$; $22,47 \%$ dan $23,80 \%$.

Kadar sari yaitu kadar ekstraktif yang terkandung dalam bahan baku umumnya terdiri atas asam-asam lemak, resin, wax, gum dan lainlain, merupakan bahan yang mudah menguap (volatile content) dan bahan yang tidak mudah menguap (unvolatile content). Menurut SNI 14-1032-1989, sari (ekstrak alkohol-benzena) adalah zat dalam kayu atau pulp yang terekstraksi oleh alkohol-benzena sebagai pelarut, dilakukan pada titik didih pelarut dalam waktu tertentu. Kadar sari kulit, campuran dan batang tanpa kulit masing-masing adalah 2,29\%, 1,96\% dan $1,66 \%$. Pada umumnya, kayu yang mengandung ekstraktif rendah akan menghasilkan pulp yang bersih.

Kadar lignin kulit, campuran dan batang tanpa kulit masing-masing adalah 10,16\%; 17,04\% dan $22,75 \%$. Kandungan lignin yang tinggi dalam bahan baku akan mengkonsumsi bahan kimia yang banyak dan dapat memberikan sifat serat yang lebih kaku dan getas. Secara umum kandungan kimia kenaf yang digunakan sebagai bahan baku sesuai dengan dengan kandungan kimia kenaf pada umumnya.

\section{Rendemen Pulp Kimia Mekanis}

Hasil pembuatan pulp dengan proses kimia mekanis dapat dilihat pada Gambar 2. Gambar 2 menunjukkan bahwa semakin besar dosis $\mathrm{NaOH}$ yang digunakan semakin kecil rendemen pulp yang dihasilkan.

Kulit kenaf memiliki rendemen yang paling rendah dibandingkan dengan campuran atau batang tanpa kulit. Hal ini disebabkan karena kulit kenaf memiliki kandungan lignin yang lebih rendah dari campuran atau batang tanpa kulit, sehingga rendemen pulp kimia mekanis dominan kandungan selulosanya sedangkan pulp kimia mekanis campuran dan batang masih mengandung kandungan lignin yang lebih tinggi dibanding pulp kimia mekanis kulit. Serpih kulit kenaf lebih tipis dibandingkan dengan campuran ataupun batang tanpa kulit sehingga penetrasi larutan kimia lebih cepat. Rendemen yang diperoleh masih lebih tinggi dibandingkan dengan pembuatan pulp soda antrakuinon (51 - 58\%) yang dilakukan oleh Mosello dkk. (2010), tetapi lebih rendah bila dibandingakan dengan pulp kenaf yang dibuat melalui proses Termo Mekanis (TMP) dan Kimia Termo Mekanis (CTMP) yang memberikan rendemen $86-91 \%$ (Haroen, 2008). 


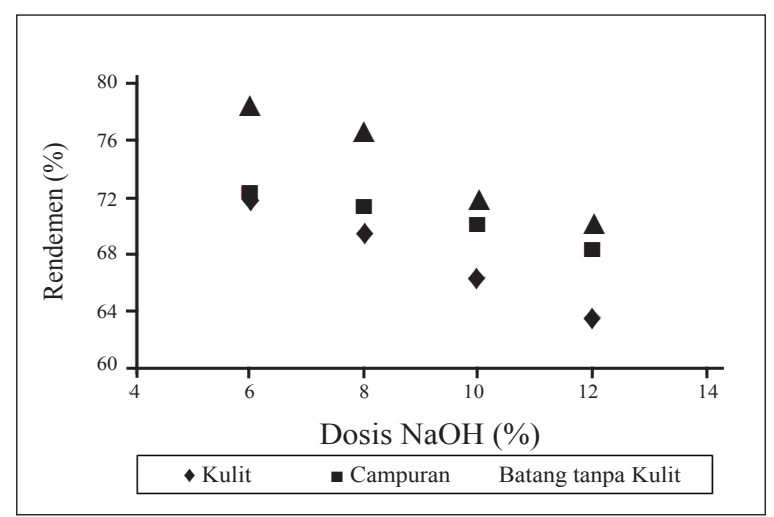

Gambar 2. Pengaruh Dosis $\mathrm{NaOH}$ terhadap Rendemen Pulp

\section{Sifat Fisik Lembaran Pulp Kenaf}

Hasil pengujian sifat fisik lembaran pulp dibandingkan dengan persyaratan spesifikasi pulp kraft belum putih kayujarum atau NUKP. Berdasarkan hasil evaluasi sifat fisik lembaran pulp diperoleh bahwa kekuatan fisik lembaran pulp kimia mekanis yang dibuat dari kulit kenaf memenuhi persyaratan spesifikasi pulp kraft belum putih kayu jarum. Dosis $\mathrm{NaOH} 6 \%$ sudah cukup untuk memenuhi kriteria spesifikasi NUKP. Apabila dilihat dari nilai indeks tarik pulp kimia mekanis dari campuran, pulp tersebut mempunyai potensi cukup baik sebagai bahan baku kertas lainer karena nilainya di atas spesifikasi pulp NUKP. Spesifikasi pulp kimia mekanis dari bagian tanaman kenaf dapat dilihat pada Tabel 5.

Nilai indeks tarik pulp campuran lebih tinggi daripada pulp kulit dan pulp batang tanpa kulit, menunjukkan bahwa pulp dari campuran kulit dan batang kenaf mempunyai potensi sebagai bahan baku dalam pembuatan kertas lainer.

Tabel 5. Spesifikasi Pulp Kimia Mekanis Bagian Tanaman Kenaf

\begin{tabular}{|c|c|c|c|c|c|c|c|c|}
\hline \multirow{2}{*}{ No } & \multirow{2}{*}{ Jenis Pulp } & \multirow{2}{*}{ Parameter } & \multirow{2}{*}{ Satuan } & \multirow{2}{*}{$\mathrm{SNI}^{*}$} & \multicolumn{4}{|c|}{ Konsentrasi $\mathrm{NaOH}$} \\
\hline & & & & & $6 \%$ & $8 \%$ & $10 \%$ & $12 \%$ \\
\hline \multirow{5}{*}{1} & \multirow{5}{*}{$\begin{array}{l}\text { Pulp Mekanis } \\
\text { Kulit Kenaf }\end{array}$} & Panjang serat rata-rata & $\mathrm{mm}$ & Min. 2 & \multicolumn{4}{|c|}{4,24} \\
\hline & & Derajat giling awal & $\mathrm{mL} \mathrm{CSF}$ & Min. 700 & 760 & 740 & 735 & 710 \\
\hline & & $\begin{array}{l}\text { Indeks tarik pada } \\
300 \mathrm{~mL} \mathrm{CSF}\end{array}$ & $\mathrm{Nm} / \mathrm{g}$ & Min. 65 & 66,54 & 66,40 & 68,37 & 80,47 \\
\hline & & $\begin{array}{l}\text { Indeks retak pada } \\
300 \mathrm{~mL} \mathrm{CSF}\end{array}$ & $\mathrm{kPam}^{2} / \mathrm{g}$ & Min. 5,5 & 5,72 & 5,99 & 6,02 & 6,64 \\
\hline & & $\begin{array}{l}\text { Indeks sobek pada } \\
300 \mathrm{~mL} \mathrm{CSF}\end{array}$ & $\mathrm{mNm}^{2} / \mathrm{g}$ & Min. 10,0 & 18,09 & 18,95 & 19,70 & 20,48 \\
\hline \multirow{5}{*}{2} & \multirow{5}{*}{$\begin{array}{l}\text { Pulp Mekanis } \\
\text { Campuran }\end{array}$} & Panjang serat rata-rata & $\mathrm{mm}$ & Min. 2 & \multicolumn{4}{|c|}{2,82} \\
\hline & & Derajat giling awal & $\mathrm{mL} \mathrm{CSF}$ & Min. 700 & 700 & 690 & 710 & 720 \\
\hline & & $\begin{array}{l}\text { Indeks tarik pada } \\
300 \mathrm{~mL} \text { CSF }\end{array}$ & $\mathrm{Nm} / \mathrm{g}$ & Min. 65 & 71,33 & 77,48 & 84,04 & 55,54 \\
\hline & & $\begin{array}{l}\text { Indeks retak pada } \\
300 \mathrm{~mL} \mathrm{CSF}\end{array}$ & $\mathrm{kPam}^{2} / \mathrm{g}$ & Min. 5,5 & 4,46 & 4,91 & 4,98 & 5,16 \\
\hline & & $\begin{array}{l}\text { Indeks sobek pada } \\
300 \mathrm{~mL} \mathrm{CSF}\end{array}$ & $\mathrm{mNm}^{2} / \mathrm{g}$ & Min. 10,0 & 7,66 & 7,69 & 9,02 & 9,98 \\
\hline \multirow{5}{*}{3} & \multirow{5}{*}{$\begin{array}{l}\text { Pulp Mekanis } \\
\text { Batang Kenaf } \\
\text { tanpa Kulit }\end{array}$} & Panjang serat rata-rata & $\mathrm{mm}$ & Min. 2 & \multicolumn{4}{|c|}{1,21} \\
\hline & & Derajat giling awal & $\mathrm{mL} \mathrm{CSF}$ & Min. 700 & 690 & 650 & 640 & 610 \\
\hline & & $\begin{array}{l}\text { Indeks tarik pada } \\
300 \mathrm{~mL} \mathrm{CSF}\end{array}$ & $\mathrm{Nm} / \mathrm{g}$ & Min. 65 & 55,54 & 62,31 & 68,54 & 73,54 \\
\hline & & $\begin{array}{l}\text { Indeks retak pada } \\
300 \mathrm{~mL} \text { CSF } \\
\end{array}$ & $\mathrm{kPam}^{2} / \mathrm{g}$ & Min. 5,5 & 1,72 & 2,18 & 3,20 & 3,72 \\
\hline & & $\begin{array}{l}\text { Indeks sobek pada } \\
300 \mathrm{~mL} \mathrm{CSF}\end{array}$ & $\mathrm{mNm}^{2} / \mathrm{g}$ & Min. 10,0 & 3,20 & 3,64 & 3,80 & 4,26 \\
\hline
\end{tabular}

*SNI 14-6106-1999 - Pulp kraft belum putih kayujarum (NUKP) 


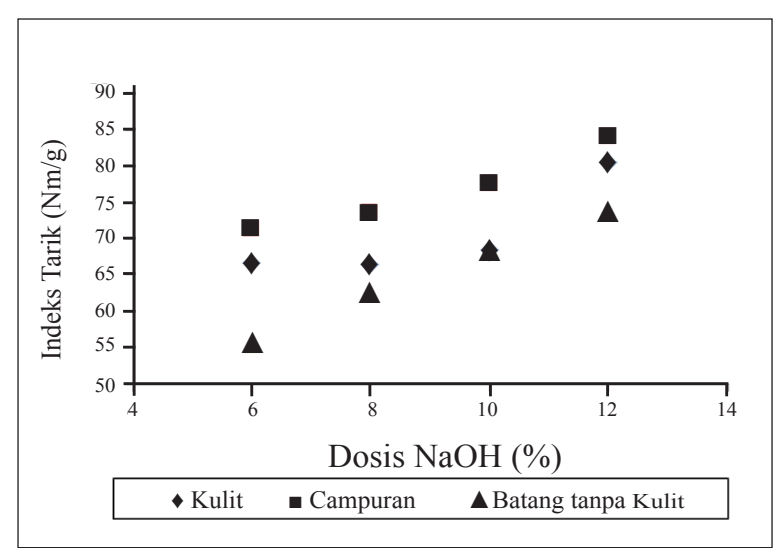

Gambar 3. Pengaruh Dosis NaOH terhadap Indeks Tarik

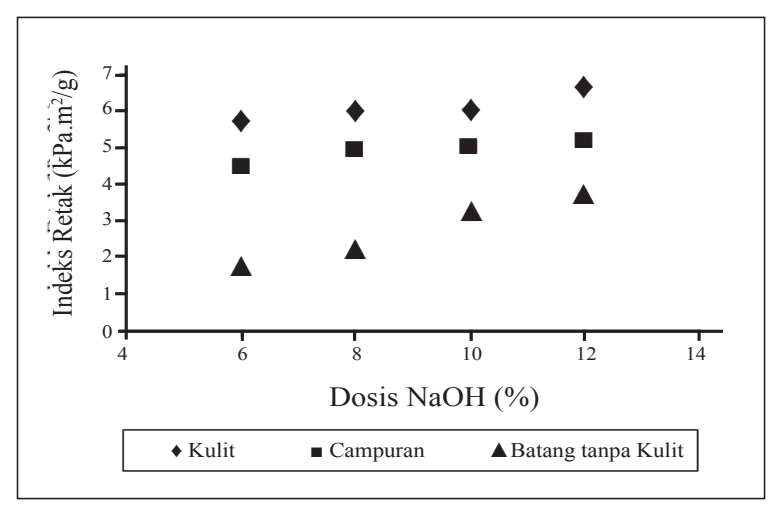

Gambar 4. Pengaruh Dosis $\mathrm{NaOH}$ terhadap Indeks Retak

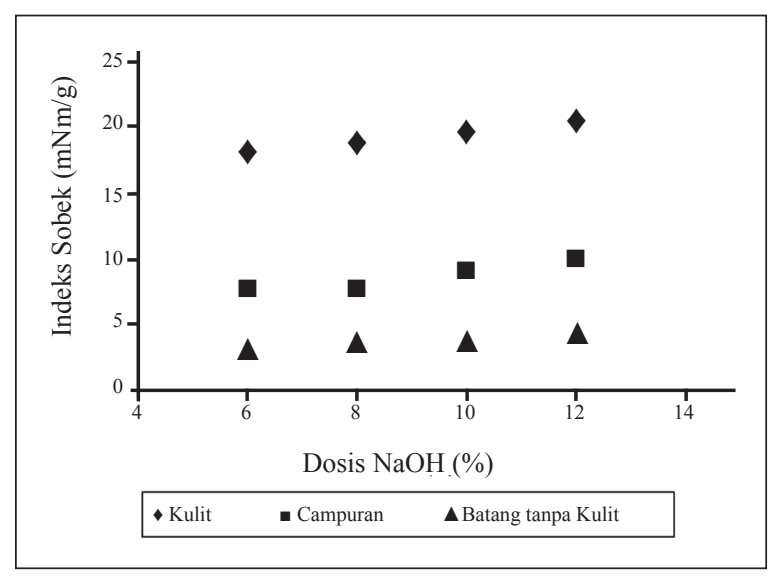

Gambar 5. Pengaruh Dosis $\mathrm{NaOH}$ terhadap Indeks Retak

Indeks retak pulp kulit kenaf paling tinggi dibandingkan pulp campuran dan batang tanpa kulit. Karakteristik ini sesuai untuk bahan baku kemasan yang mempersyaratkan kekuatan retak yang tinggi, sehingga kulit kenaf sesuai untuk dijadikan bahan baku pembuatan kertas lainer.
Indeks sobek kulit kenaf paling tinggi dibandingkan campuran dan batang tanpa kulit. Hal ini sesuai dengan serat kulit yang lebih panjang dan nilai daya tenunnya yang lebih tinggi daripada batang tanpa kulit.

\section{KESIMPULAN}

Hasil penelitian menunjukkan bahwa panjang serat kulit kenaf 4,24 mm termasuk dalam klasifikasi serat panjang dan batang kenaf $1,41 \mathrm{~mm}$ termasuk dalam klasifikasi serat sedang. Komposisi kimia tanaman kenaf yang digunakan dalam penelitian ini sesuai dengan komposisi tanaman kenaf pada umumnya dan dapat digunakan sebagai bahan baku pulp kimia mekanis. Selulosa alfa kulit kenaf, campuran dan batang tanpa kulit berturut-turut sebesar 45,90 $\%, 39,82 \%$ dan $38,53 \%$. Kenaf dapat dibuat pulp kimia mekanis dengan menghasilkan rendemen yang cukup tinggi dengan rentang antara $63 \%-78 \%$. Pulp kimia mekanis dari kulit kenaf dengan dosis $\mathrm{NaOH} 6 \%$ memenuhi persyaratan spesifikasi pulp kraft belum putih kayu jarum, yaitu panjang serat $4,24 \mathrm{~mm}$, freeness $760 \mathrm{~mL}$ CSF, indeks tarik $66,54 \mathrm{Nm} / \mathrm{g}$, indeks retak 5,72 $\mathrm{kPam}^{2} / \mathrm{g}$ dan indeks sobek $18,09 \mathrm{mNm}^{2} / \mathrm{g}$.

\section{UCAPAN TERIMA KASIH}

Terima kasih penulis sampaikan kepada Balai Besar Pulp dan Kertas atas dana penelitian yang diberikan dan kepada para teknisi litkayasa yang membantu terlaksananya penelitian ini.

\section{DAFTAR PUSTAKA}

Aprianis, Y. dan Rahmayanti, S. 2009. Dimensi Serat dan Nilai Turunannya dari Tujuh Jenis Kayu Asal Propinsi Jambi. Jurnal Penelitian Hasil Hutan. Vol.27, No. 1, 11-20.

Calabro, G. 1992. Kenaf pulp properties as a function of their composition: Yield and Freeness. Paper presented at the Pulping Conference, 1-5 November, Boston MA, Book 2, TAPPI Press, Atlanta.

FAO. 2006. Jute, Kenaf, Sisal, Abaca, Coir and Allied Fibers Statistics. http://www.fao.org/ es/esc/en/20953/21005/highlight_51023en. html

Han, J. S. 1998. Properties of Nonwood Fibers. Proceedings of The Korean Society of Wood Science and Technology. page 3-12. 
Haroen, W.K. 2008. Pulp Termo Mekanis (TMP) dan Kimia Termo Mekanis (CTMP) dari Limbah Batang Kenaf. J. Tropical Wood Science and Technology. Vol. 6,No. 2, 6974.

Ibrahim, M., Daud, W.R.W., Law, K. N. 2011. Comparative Properties of Soda Pulps from Stalk, Bast, and Core of Malaysian Grown Kenaf.

Kaldor, A. F. 1989. Preparation of kenaf bark and core fibers for pulping by the alkaline method. Tappi Journal. 72:137-140.

Khalil, H. P. S. A., Ireana Yusra, A. F., Bhat, A. H., and Jawaid, M. 2010. Cell wall ultrastructure, anatomy, lignin distribution, and chemical composition of Malaysian cultivated kenaf fiber. Industrial Crops \& Products 31(1), 113-121.

Khristova, P., Kordsachia, O., Patt, R., Khider, T., and Karrar, I. 2002. Alkaline pulping with additives of kenaf from Sudan. Industrial Crops \& Products 15(3):229-235.

Liu, A. 2002. World Production and Utilization of Jute, Kenaf, and Allied Fibers. http:// www.chinaconsulting.com/kenafworkshop. htm. diakses 8 Maret 2009.

Mossello, A. A., Ainun, Z. M. A., and Rushdan, I. (2009). Chemical, morphological, and technological properties of Malaysian cultivated kenaf (Hibiscus cannabinus L.) fibers. Kenaf Biocomposites, Derivatives \& Economics. Pustaka Prinsip Sdn. Bhd. Bandar Baru Seri Petaling, Kuala Lumpur.

Mossello, A.A., Harun, J., Ibrahim, R., Resalati, H., Shamsi, S. R. F., Tanir, P. M.,dan Yusoff, M. N. M. 2010. Evaluation of lainerboard properites from Malaysian cultivated kenaf soda-anthraquinone pulps versus commercial pulps. BioRes. 5(3), 1595-1604
Mossello, A. A., Ainun, Z. M. A., Harun, J., Resalati, H., Shamsi, S.R.F., and Rushdan, I. 2010. A Review of Literatures Related of using Kenaf for Pulp Production (Beating, Fractionation, and Recycled Fiber). Modern Applied Science. Canadian Center of Science and Education. Vol. 4, No. 9

Nezamoleslami, A., Suzuki, K., and Kadoya, T. 1997. Preparation and properties ofretted kenaf bast fiber pulp and evaluation as substitute for Manila hemp pulp. J. Pack. Sci. Technol. 6, 339-347

Nurrahman, A dan Silitonga, T., 1972. Dimensi Serat Beberapa Jenis Kayu Sumatera Selatan. Laporan No.2, LPHH, Bogor

Ren, W., Du, H., Zhang, M., and Ni, Y. 1996. Characterization of Chinese kenaf bark fibers for production of bleached chemical pulp. IPPTA 8(2), 1-7

Rulliati, S. dan Lempang, M., 2004. Sifat anatomi dan fisis kayu jati dari Muna dan Kendari Selatan. Jurnal Penelitian Hasil Hutan. Vol. 22 No. 4, $231-237$

Syafii, W. dan Siregar, I. Z., 2006. Sifat kimia dan dimensi serat kayu mangium (Acacia mangium Willd.) dari tiga provenans. Jurnal Ilmu dan Teknologi Kayu Tropis. Vol. 4. No.1, 29-32

Ververis, C., Georghiou, K., Christodoulakis, N., Santas, P., and Santas, R. 2004. Fiber dimensions, lignin and cellulose content of various plant materials and their suitability for paper production. Industrial Crops \& Products, 19(3), 245-254

Villar, J. C., Revilla, E., Gómez, N., Carbajo, J. M., and Simón, J. L. 2009. Improving the use of kenaf for kraft pulping by using mixtures of bast and core fibers. Industrial Crops \& Products 29(2-3), 301-307 
Lurnal Selulosa, Vol. 4, No. 1, Juni 2014: 37 - 46 